6. Гнєтнєв М. К., Сінгаївська І. В. Про ключові аспекти кваліфікації злочинів, передбачених статтями 146 і 147 КК України. Вісник Луганського державного університету внутрішніх справ імені Е. О. Дідоренка. 2017. № 1 (77). С. 44-53.

DOI https://doi.org/10.30525/978-9934-26-148-0-40

\title{
ПРОБЛЕМНІ АСПЕКТИ КВАЛІФІКАЦІЇ ПОРУШЕННЯ НЕДОТОРКАНОСТІ ПРИВАТНОГО ЖИТТЯ
}

\author{
Томчук I. O.
}

кандидат юридичних наук, дочент кафедри права

Галицького коледжу імені В 'ячеслава Чорновола

\section{Хлипавка В. I.}

здобувач вищої освіти юридичного відділення

Галицького коледжу імені В 'ячеслава Чорновола

м. Тернопіль, Україна

Приватне життя та особиста недоторканість є основою правового статусу особи у суспільстві та державі. Україна розпочала демократичні перетворення шляхом посилення контролю за захистом приватного життя своїх громадян, а також удосконалення законодавства у сфері відповідальності за порушення одного із основних засад демократичної держави.

Питанням кваліфікації кримінального правопорушення «Порушення недоторканості приватного життя» впродовж останніх років присвячені праці таких науковців як Сосніна О.В., Мацура Н.А., Матвійчук В.В., Савченко А.В., Тавлуй О. та ін. Проте і надалі залишаються невирішеними окремі питання відмежування даного кримінального проступку від суміжних складів кримінальних правопорушень.

Відповідно до статті 182 Кримінального кодексу України (далі - КК України) кримінально караними $є$ такі дії: «незаконне збирання, зберігання, використання, знищення, поширення конфіденційної інформації про особу або незаконна зміна такої інформації, крім випадків, передбачених іншими статтями цього Кодексу» [1]. Таким чином, предметом цього кримінального правопорушення є конфіденційна інформація. До такої інформації про особу належать ті відомості, які становлять особисту чи сімейну таємницю особи. 
Особиста таємниця особи - інформація про стан здоров'я, майновий стан, дату народження, рівень освіти, прізвище, ім'я, по батькові, місце народження та адресу проживання, вид професійної діяльності, доходи, звички особи, спосіб життя, віросповідання, про факти біографії особи, захоплення, творчі заняття, погляди, переконання, відносини з іншими особами, уподобання, симпатії і антипатії, інтимні стосунки з іншими особами, наявність інтимних позашлюбних стосунків, народження дитини поза шлюбом [2].

Сімейну таємницю особи складають відомості про сімейний стан, сімейні відносини, інтимні стосунки у сім'ї, приватне життя члена сім'ї, які особа бажає зберегти у таємниці від інших сторонніх осіб, майновий стан родичів особи, родинні стосунки, відомості, якими володіють члени сім'ї і в розголошенні яких вони не зацікавлені [3, с. 52; 4, с. 53].

Слід зазначити, що відповідно до примітки статті 182 КК України публічне, у тому числі через засоби масової інформації, журналістів, громадські об'єднання, професійні спілки, повідомлення особою інформації про вчинення кримінального або іншого правопорушення, здійснене 3 дотриманням вимог закону, не є кримінально караними діями.

Аналіз зарубіжного законодавства дозволяє порівняти національну правову систему у співвідношенні з правовими системами інших держав. Наприклад, Кримінальний кодекс Литовської Республіки злочини i кримінальні проступки проти конституційних прав і свобод людини i громадянина розмістив у чотирьох розділах, а правовий захист недоторканності приватного життя регламентується окремою главою «Злочини проти недоторканності приватного життя особи», в якій містяться норми, що встановлюють відповідальність за незаконне порушення недоторканності житла особи, таємниці листування, за незаконне збирання, розголошення, використання відомостей про приватне життя особи (статті 165-168). Це свідчить про важливість охорони приватного життя. Норма, що міститься у ч. 1 ст. 167 Кримінального кодексу Литовської Республіки встановлює відповідальність за незаконне збирання відомостей про приватне життя особи [5, с. 61].

У зв'язку із відсутністю чіткого переліку відомостей, що характеризують приватність життя та кримінальними правопорушеннями, що містять ознаки порушення приватного життя, наприклад, стаття 163 КК України «Порушення таємниці листування, телефонних розмов, телеграфної чи іншої кореспонденції, що передаються засобами зв'язку або через комп'ютер» та стаття 168 КК України «Розголошення таємниці усиновлення (удочеріння)», доцільно провести розмежування між зазначеними діяннями. 
Таким чином, розглянувши положення ст. 168 КК України, насамперед, варто зазначити що відмінністю $є$ те, що ознаки цього складу злочину є спеціальними від складу ст. 182 КК України. Тавлуй Олена 3 цього приводу зазначає, що розголошення таємниці усиновлення (удочеріння) є більш суспільно небезпечним злочином, ніж порушення недоторканності приватного життя та покликана забезпечити охорону прав та інтересів дитини, а тому це діяння виділене в окрему норму кодексу [6, с. 194].

На нашу думку, у випадку збирання конфіденційної інформації про особу, яке було поєднане із порушенням таємниці кореспонденції, таке діяння варто кваліфікувати за сукупністю кримінальних правопорушень, передбачених статтями 182 та 163 КК України. У судовій практиці також можна знайти випадки такої кваліфікації за сукупністю цих статей. Наприклад, в ухвалі Апеляційного суду Чернігівської області від 03 грудня 2008 року було залишено без зміни вирок суду першої інстанції, в якому було кваліфіковано за сукупністю ч. 3 ст. 359 , ч. 1 ст. 163, ст. 182 КК України дії групи осіб за попередньою змовою, які протягом тривалого строку за допомогою спеціальних технічних засобів негласного отримання інформації здійснювали прослуховування телефонних розмов щодо державних та громадських діячів та незаконно збирали і зберігали відповідну конфіденційну інформацію про особу [7].

Підсумовуючи вищезазначене, можна стверджувати, що основною проблемою, на сьогоднішній день, при призначенні покарання за вчинення проступку «Порушення недоторканості приватного життя» залишається відсутність законодавчого закріплення відомостей, які відносяться до сфери приватного та сімейного життя, тобто немає чітко визначеного предмету цього кримінального правопорушення. Це знаходить своє відображення у неточності трактування дій правопорушника та неможливості притягнення його у певних випадках до кримінальної відповідальності. Вирішення цієї прогалини можливе шляхом внесення відповідних змін до чинного Кримінального кодексу України у частині визначення поняття конфіденційної інформації, що сприятиме кримінально-правовому забезпеченню протидії даному правопорушенню.

\section{Лiтература:}

1. Кримінальний кодекс України від 05.04.2001. № 2341-III. Дата оновлення: 08.08.2021. URL: https://zakon.rada.gov.ua/laws/show/2341 14\#Text (дата звернення: 26.09.2021). 
2. Сайт Конституційного суду України. URL: https://ccu.gov.ua/ storinka-knygy/428-pravo-na-nedotorkannist-osobystogo-zhyttya (дата звернення 26.09.2021).

3. Мацура Н.А., Сосніна О.В. Щодо об’єкта складу порушення недоторканності приватного життя. Вісник Львівського торговельноекономічного університету. Юридичні науки. 2021. № 9. С. 50-56. URL: http://journals-lute.lviv.ua/index.php/visnyk-law/article/view/932/ 883 (дата звернення: 26.09.2021).

4. Іщенко А. О. Поняття особистого життя людини: розбіжності у визначенні. Право і суспільство. 2020. № 2. С. 51-56. URL: https://doi.org/ 10.32842/2078-3736/2020.2-1.9 (дата звернення: 26.09.2021)

5. Сосніна О.В. Кримінальна відповідальність за порушення недоторканості приватного життя (ст. 182 КК України) : дис. ... канд. юр. наук : 12.00.08. Львів, 2017. 256 c. URL: http://ena.lp.edu.ua/bitstream/ ntb/36922/3/dis_mukan_o.v.pdf (дата звернення: 27.09.2021).

6. Тавлуй $\mathrm{O}$. Розголошення таємниці усиновлення: окремі аспекти відмежування від інших правопорушень. Підприємництво, господарство і право. 2021. № 6. C.192-195. URL: https://doi.org/10.32849/ 2663-5313/2021.6.30 (дата звернення: 27.09.2021).

7. Єдиний Державний Реєстр Судових Рішень. URL: https://reyestr.court.gov.ua/Review/2695127 (дата звернення: 05.10.2021p.) 